\title{
Entrepreneurial Orientation as a Determinant of Oil and Gas Service Firm Performance in Nigeria: The Moderating Role of External Environment
}

\author{
M. A. Arokodare ${ }^{1} \&$ O. U. Asikhia ${ }^{1}$ \\ ${ }^{1}$ Department of Business Administration and Marketing, Babcock University, Illisan-Remo, Sagamu, Ogun State, \\ Nigeria \\ Correspondence: M. A. Arokodare, Department of Business Administration and Marketing, Babcock University, \\ Illisan-Remo, Sagamu, Ogun State, Nigeria. E-mail: biodunarokodare@yahoo.com
}

Received: April 26, 2020

Accepted: May 11, 2020

Online Published: May 25, 2020

doi:10.5430/jms.v11n2p1

URL: https://doi.org/10.5430/jms.v11n2p1

\begin{abstract}
Oil and gas service sector is one of the major sectors of the oil and gas industry that contributes to and enhances economic functions across the globe. This industry in Nigeria was plagued with problems of unstable global oil prices, absence of entrepreneurial mindset, poor entrepreneurship ideas and mis-match of entrepreneurial orientation strategies with local and international business environmental conditions. Due to these problems, the oil and gas service firms recorded declining market performance and profitability. This study therefore examined the effect of entrepreneurial orientation components on overall performance. The study adopted cross-sectional survey research design with a target population of 14,038 owners and managers of oil and gas service companies operating in Nigeria. A mixed sampling technique was adopted to select the sample size of 576 using the Cochran (1997) formula. The data was analyzed using descriptive statistics and multiple and hierarchical regression methods of analyses. Findings revealed that entrepreneurial orientation components (proactiveness, innovativeness, risk taking propensity, autonomy and competitive aggressiveness) had significant effect on market performance $\left(\right.$ Adj. $\mathrm{R}^{2}=.538$, F-stat $=$ $92.142, \mathrm{p}<0.05$ ). Entrepreneurial orientation components significantly affected profitability (Adj. $R^{2}=.626$, F-stat $=$ 76.584, $\mathrm{p}<0.05$ ); while external environment significantly moderated the relationship between entrepreneurial orientation and firm performance $\left(\Delta A d j . \mathrm{R}^{2}=.593, \Delta \mathrm{F}=25.451 ; \mathrm{F}\right.$-stat $\left.=47.215, \mathrm{p}<0.05\right)$ all at $5 \%$ level of significance. Implications of the findings and recommendations were made.
\end{abstract}

Keywords: entrepreneurial orientation, external environment, firm performance, oil and gas service industry

JEL Codes: L1, M1

\section{Introduction}

In the 21st century, businesses around the globe cannot survive and achieve targeted overall performance without dynamic entrepreneurial ideas involving identification of new opportunities, responding fast to environmental changes and taking appropriate actions aimed at reaching the desired goal. Businesses across different sectors, oil and gas service industry inclusive, do encounter challenges from unpredictable global shocks and changes in business environmental factors which have hindered overall performance of the oil and gas sector. Asikhia and Arokodare (2019) argued that overall performance in terms of market share control, sales growth and profitability were volatile across oil and gas industry in developed, emerging and developing countries resulting from swift changes in the domestic and international business environmental conditions coupled with mis-match of sound entrepreneurial orientation with global trends.

Among oil and gas multinational firms in Europe and Middle East, Zafari (2017) pointed out that majority of them experienced challenges of decline in financial performance and market share. These challenges could be traced to lack of adequate entrepreneurial skills, changes in market force environment, inflexible planning towards global oil price depression, unstable macroeconomic policies and oil price volatility that characterized the oil and gas global industry (Asikhia \& Arokodare, 2019; Zafari, 2017). Adesanya et al. (2018) asserted that volatile business environment stressors and competitiveness issues characterized the oil and gas industry in Nigeria with under-capacitated entrepreneurial orientation strategies in terms of risk-taking, pro-activeness and innovativeness 
propensities. Specifically, Ihua et al. (2011) asserted that these companies suffer from low technological capacity, lack of funding from local and foreign financial institutions, absence of and/or inadequate, and incoherent policies/legislations, inadequate infrastructure, unfavourable business climate, unwillingness of foreign companies, who are found to be superior and technically competent, to partner with the indigenous contractors. These created challenges of continuous dilemma in the oil and gas industry performance that are common with developing economies like Nigeria.

The Nigerian oil and gas industry had been vibrant since the discovery of crude oil in 1956 by the Shell Group. The sector contributes significantly to Nigeria's economy: according to the foreign trade data of National Bureau of Statistics (2018), for the first quarter of 2018, the contribution of the oil sector (with the associated gas components) to the real Gross Domestic Product (GDP) of the nation was about $9.61 \%$ (14.75\% same quarter in 2014). In the same quarter, crude oil and oil products made up $87.7 \%$ of Nigeria's foreign exchange earnings. This was made up of sales of crude oil and sales of processed oil products like condensates and lubricants which accounted for $76.3 \%$ and $11.4 \%$ of the nation's export earnings respectively. From 1999 to 2015, oil exports represented more than $90 \%$ of Nigeria's exports; oil revenue was about $70 \%$ of the total national revenue; however, the oil sector's contribution to GDP averaged about 13\% over the same period (Agbaeze \& Ukoha, 2018). Other areas where this sector contributes to national economic development includes the attraction of foreign direct investment into the country especially in the oil sector, provision of cheap and readily available source of energy, boosting of the foreign reserves, and provision of employment (Asagunla \& Agbede, 2018). The significance of the industry's contribution made Nigeria to be one of the most oil-dependent economies in the world. Hitherto, the sector was largely dominated by multinational corporations until the early 1990's when Nigerian companies began to make a foray into the industry. This development was significantly promoted and boosted by the promulgation into law of the Nigerian Oil and Gas Industry Content Development Act, 2010.

Nigeria as an oil dependent economy and a member of the Organisation of Petroleum Exporting Countries (OPEC), obtains most of its national revenue from crude oil exploration, production and exportation. In the oil market, crude oil price is highly volatile and the invisible hands of international market forces strike down oil and gas industry performance. Despite the existence of different agencies that monitor and control the business functions of the oil and gas industry and innovative programmes in Nigeria, the World Bank Nigerian Economic Report (2019) stipulated that entrepreneurship development in the oil and gas industry in Nigeria still faces myriads of challenges of declining oil and gas aggregate financial performance, incapacitated entrepreneurial ideas and non-strategic responses to oil and gas global forces that are usually dynamic. Adesanya et al. (2018) pointed out that majority of oil and gas service firms in Nigeria suffer decline in overall performance due to poor entrepreneurial orientation strategies. This was supported by Asikhia and Arokodare (2019) that oil and gas service firms in Nigeria also experienced a decline in profitability and turnover rate due to unsound entrepreneurial orientation measures in risk taking and proactiveness, and poor innovation towards dynamic and complex trend in oil and gas businesses. Arokodare (2018) had earlier asserted that poor environmental consideration in strategic planning process by stakeholders in the Nigerian oil and gas service industry caused continuous deterioration in their overall performance.

Although past studies (Adesanya et al., 2018; Adi, 2015; Boohene, 2018; Eisenhardt, 2013; Gupta et al., 2015; Hakala, 2011; Maragia, 2008; Masona et al., 2015; Nikolov \& Urban, 2013; Olawoye, 2016; Patzelt \& Shepherd, 2009; Rauch et al., 2009; Ribeiro-Soriano \& Urbano, 2010; Rigtering et al., 2017; Song et al., 2019; Sumiati et al., 2019; Van Doorn et al., 2017; Wales et al., 2019; Zhao et al., 2013 among others) have examined the relationship between entrepreneurial orientation, environmental uncertainty and organizational performance in different sectors but there exist paucity of studies that examined the moderating effect of external environment on the link between entrepreneurial orientation and market performance of oil and gas service firms across economies. Likewise, to the best of researcher's knowledge, no known studies within Nigeria context investigated whether external environment moderates the relationship between entrepreneurial orientation and market performance of oil and gas service firms in Nigeria. Though Adesanya et al. (2018), Arokodare (2018), and Asikhia and Arokodare (2019) stressed that oil and gas service firms in Nigeria were faced with the problem of decline in performance resulting from unsound entrepreneurial orientation measures. Putting the gaps and problems identified in the oil and gas service industry into consideration, this study intends to investigate:

(i) Effect of entrepreneurial orientation components (proactiveness, innovativeness, risk taking propensity, autonomy and competitive aggressiveness) on market performance of oil and gas service companies in Nigeria; 
(ii) Effect of entrepreneurial orientation components (proactiveness, innovativeness, risk taking propensity, autonomy, and competitive aggressiveness) on profitability of oil and gas service companies in Nigeria; and

(iii) Moderating effect of external environment on the relationship between entrepreneurial orientation and firm performance of oil and gas service companies in Nigeria.

The rest of this article is structured as follows. Section 2 reviews existing literature on the study variables, and develops the theoretical framework and the hypotheses. Section 3 describes the methodology adopted for the study and operationalization of variables. Section 4 reports the main results. Section 5 presents the article's conclusions, highlighting the academic and managerial implications. The last section outlines the limitations of the study and suggestions for future studies.

\section{Literature Review and Hypotheses Development}

This sub-section is comprised of conceptual definitions of the study variables entrepreneurial orientation, market performance and external environment, synchronization of empirical findings, theoretical framework and empirical gap as well as hypotheses development.

\subsection{Entrepreneurial Orientation}

Conceptually, Ketchen and Short (2012) and Lumpkin and Dess (1996) defined entrepreneurial orientation (EO) as a process, practice, and decision-making style of organizations that act entrepreneurially. Similarly, Ketchen and Short (2012) viewed EO as a means of exploiting opportunities that competitors cannot pursue. Adesanya et al. (2018) defined EO as business psychology in pursuing entrepreneurial ventures, the process and their practices in order to make informed business decisions. Numerous scholars pointed out that EO is a combination of innovativeness, proactiveness, and risk taking (Covin \& Slevin, 1991; Ketchen \& Short 2012; Schillo, 2011; Zahra \& Garvis, 2000). However, Lumpkin and Dess (1996) broadened the dimensions of EO with autonomy and competitive aggressiveness mind-sets. In other words, EO is characterised by five attributes: innovativeness, risk taking, pro-activeness, competitive aggressiveness and autonomy.

Adesanya et al. (2018) and Lisboa et al. (2011) conceptualized pro-activeness as a firm's initiative process in anticipating and seizing future opportunities in the market and to pioneer new changes in processes and products. Proactiveness as a dimension of EO refers to the will and foresight to seize new opportunities (Olawoye, 2016). To Montoya et al. (2017), proactiveness is the use of new concepts and measures to develop new or improved technology, processes and product and the ultimate introduction of the products to the market system in order to seize marketplace opportunities and gain competitive advantage. Bloch and Bhattacharya (2016) and Ariguzo et al. (2018) viewed innovativeness as a central prerequisite of achieving competitiveness in the industry. Risk-taking relates to a business readiness to pursue opportunities despite uncertainty around the eventual success (Deakins \& Freel, 2012). Ariguzo et al. (2018) asserted that risk-taking entails organisations acting boldly without knowing the consequences. Competitive aggressiveness is the process efforts a business organisation makes to outperform its competitors (Ariguzo et al., 2018) and is also conceptualized by DeepaBabu and Manalel (2016) as a firm's propensity to directly and intensely challenge its competitors to achieve entry or improve position in order to outperform industry rivals in the marketplace. To Lumpkin and Dess (2001), autonomy is the individual or team action aimed at accomplishing a business concept or vision and committed to completion; it includes the concept of free and independent action and decisions taken. It deals with the predisposition toward suitable conditions for development and the subsequent implementation of innovative ideas (Fadda, 2018). In this study, autonomy is the ability to make organizational decisions and to proceed with independent management action in order to bring about a new venture, a business concept or vision, without any restrictions from the organizational structure. Generally, EO enables a firm to conceptualise and develop new ideas, practicalise and realize them in the form of new products and services, be involved in risky projects, anticipate and predict future requirements, and identify and exploit new market opportunities (Kosa et al., 2018). Specifically, the contemporary dynamic business environment requires a firm to sustain or find a new position in the market place, must innovate regularly, take risk into account in its business operations, give room for autonomy, be proactive, and aggressively compete with its rivals (Omisakin et al., 2016).

In view of above conceptual review related to the study variables, this study adopted a multi-dimensional definition of EO such as proactiveness, innovativeness, risk taking propensity, autonomy and competitive aggressiveness in setting the items of building the questionnaire in this study. This is congruent with earlier studies like (Dai et al., 2014; Fadda, 2018; George \& Marino, 2011; Hughes \& Morgan, 2007; Kreiser et al., 2013; Li et al., 2009). 


\subsection{Firm Performance}

Firm performance is the ability of any organization to meet its targeted financial and non-financial performance. Lebans and Euske (2006) defined firm performance as a set of financial and non-financial indicators that offer information on the level of accomplishment of objectives and results of firms. Arokodare (2018) defined firm performance as continuous growth in sales, market share and firm profitability which serves as yardstick for firm performance achievement. Santos and Brito (2012) conceptually viewed firm performance as positive attainment of financial and non-financial performance towards firm targeted financial and non-financial performance. Asikhia and Arokodare (2019) and Santos and Brito (2012) asserted that continuous growth in both financial and non-financial performance were relevant motives for the existence of a business firm and must therefore be included in any framework to measure firm performance in any industry. Selvam et al. (2016) established a comprehensive construct on firm's performance, which could be unidimensional or multi-dimensional. The multidimensional conceptual definition of firm performance identified by Selvam et al. (2016) were profitability performance, growth performance, market value performance, customers' satisfaction, employees' satisfaction, environmental performance, environmental audit performance, corporate governance performance among others; but this study defined firm performance in unidimensional concept in terms of market performance. The performance of a firm can be measured through sales revenue, sales growth, market share, profitability, competitive advantage, customer satisfaction and loyalty. Market performance as a conceptual measure for firm performance in this study, was defined as firm ability to continue maintaining growth in sales volume and market share control in the market.

\subsection{External Environment}

Mason and Dobbelstein (2016) conceptually defined external business environment as complex adaptive systems which are increasingly complex and with turbulent features towards business functions. Both Mason and Dobbelstein (2016) and Njoroge et al. (2016) further viewed business external environment as a set of relationships between agents or stakeholders in the environment that are changed by individual and business decisions taken. These relationships constantly co-create the external environment factors. The business external environment is changing faster than ever before (Kotter, 1996; Tolbert \& Hall, 2009), with those changes occurring in two major dimensions, complexity and turbulence. Njuguna-Kinyua et al. (2014) defined external environment as all forces and events outside the organization that interrupt on its business functions. Njuguna-Kinyua et al. (2014) further conceptualized external environment from five main dimensions of environment capacity, heterogeneity, environmental concentration, domain consensus and, environmental uncertainty. Environment capacity focuses on the level of resources available to an organization. Heterogeneity refers to the degree to which the organization faces different demands from different stakeholders. Environmental concentration is the distribution of resources used by the organizations while domain consensus represents the degree to which there is agreement among related organizations and other groups in the society to which organizations have the right to provide particular goods/services. Environmental uncertainty relates to environmental instability/change that is associated with broad environmental aspects such as the technology, political-legal and demographics. Literature has indicated that the external environment impacts on the EO-firm performance relationship (Lumpkin \& Dess 2001; Wiklund \& Shepherd, 2005) and both studies agree that the environment moderates the relationships between EO and firm performance. Literature also confirmed that environmental conditions play a significant role in the strategic decision-making process that occurs within SMEs and that the environments in which firms exhibit EO approaches do cause differences in the function and how they relate to performance (Kreiser et al., 2002). For example, a dynamic environment will moderate the relationship between organizational risk-taking propensity and firm performance, facilitate product innovation and enable a positive relationship with proactiveness (Lumpkin \& Dess, 2001). Furthermore, a munificent environment will positively influence risk-taking and facilitate proactiveness while on the other hand, a hostile environment will hinder experimentation and discovery initiatives that are entailed by proactiveness (Omisakin et al., 2016).

\subsection{Theoretical Foundation}

Theoretically, this study was anchored on Dynamic Capabilities Theory (DCT) which was developed by Teece et al. (1997). The DCT mitigated the shortcomings of resource-based view and resource dependence theory to explain the mechanism that links resources and product markets to competitive advantage and firm survival. The DCT explains how firms gain sustainable competitive advantage, and survive in competitive and turbulent business environments in several ways. The DCT framework works on three fundamental presumptions: the capacity to sense and shape opportunities, to seize opportunities, and to maintain competitiveness through reconfiguring the enterprise's assets (Teece, 2007). Based on a review and synthesis of the literature, a dynamic capability is the enterprise's potential to 
systematically solve problems formed by its propensity to sense opportunities and threats, make timely and market-oriented decisions and to change its resource base (Barreto, 2010; Di Stefano et al., 2010). The DCT framework advances can help scholars to understand the foundations of long-run enterprise success while helping managers delineate relevant strategic considerations and the priorities they must adopt to enhance enterprise performance and escape the zero profit tendency associated with operating in markets open to global competition (Teece, 2007). The framework integrates the strategy and innovation literature and highlights the most important capabilities that the management needs in a dynamic business environment in order to sustain superior long run business performance (Teece, 2007). Dynamic capabilities include the sensing, seizing and transforming abilities that are needed to upgrade the ordinary capabilities of an enterprise and direct them through developing and coordinating the firm's resources to address and shape changes in the marketplace or in the business environment (Teece, 2018). The DCT theory was employed as the underlying theory for this study because the DCT perspective and ideology were tied to the presumption that firms dynamically manage their resources and business environment in order to achieve competitive advantage and overall performance in terms of market share, sales growth and profitability over other competitors in the industry.

\subsection{Empirical Review of Literature}

Empirically, the relationship between EO and firm performance is one of the most researched topics in the fields of strategic management and entrepreneurship (Covin \& Slevin, 1991; Ketchen \& Short 2012; Olawoye, 2016; Saeed $e t$ al., 2014). Despite the remarkable empirical evidences on the link between EO and firm performance, the empirical findings could either be positive or negative, remain inconclusive and conflicting ( $\mathrm{Su}, \mathrm{Xie}, \& \mathrm{Li}, 2011)$. Studies such as Naldi et al. (2007) examined the link between EO and firm performance and found a negative effect between risk-taking dimension of EO and financial performance in family organizations; and Rezaei and Ortt (2018) also found a negative relationship between risk-taking and production performance. Likewise, Kosgei and Loice (2015) and Olawoye (2016) found that risk-taking as part of measures of EO has negative relationships with both returns on assets and returns on equity; while Renko et al. (2009) and Slater and Narver (2000) empirically found that EO measures did not significantly affect or determine product innovation performance.

Conversely, many studies established that EO measures have positive and significant effect on firm performance components like sales output, sales growth, profitability, revenue generation (Couto-Soares \& Perin, 2019; Fadda, 2018; Garba et al., 2019; Gudda, 2018; Irungu \& Moronge, 2018; Kimutai-Arap-Bor, 2018; Kosa et al., 2018; Peng, 2015; Syrja et al., 2019; Wambugu et al., 2016; Wiklund \& Sheperd, 2003 among others). Furthermore, the diverse empirical findings among past studies have led researchers to examine the moderating variable that may determine the relationship between EO and firm performance (Schepers et al., 2014). Majority of past studies employed learning orientation, organizational culture, firm size and characteristics (Hakala, 2013; Hult et al., 2004; Wales et al., 2013; Wang, 2008). Though literature confirmed that environmental conditions play a significant role in the strategic decision-making process that occurs within SMEs and that the environments in which firms exhibit EO approaches do cause differences in the function and how they relate to performance (Kreiser et al., 2002). Majority of past studies within and outside Nigerian context never considered the moderating effect of external environment on the relationship between $\mathrm{EO}$ and firm performance with market and profitability performances as indicators in the oil and gas service sector. As such, there is no unanimous conclusion or consensus on this matter and also there exists an empirical gap in this study area. From the empirical gap identified, hypotheses were developed in null form as follows:

$\mathbf{H}_{01}$ : Entrepreneurial orientation components (proactiveness, innovativeness, risk taking propensity, autonomy and competitive aggressiveness) do not significantly affect market performance of oil and gas service companies in Nigeria;

$\mathbf{H}_{\mathbf{0 2}}$ : Entrepreneurial orientation components (proactiveness, innovativeness, risk taking propensity, autonomy and competitive aggressiveness) do not significantly affect profitability of oil and gas service companies in Nigeria; and

$\mathbf{H}_{03}$ : There is no significant moderating effect of external environment on the relationship between entrepreneurial orientation and firm performance of oil and gas service companies in Nigeria 


\subsection{Conceptual Model}

Considering the empirical gap identified from the review of related past studies, this is depicted in the conceptual model which relates how EO components affect firm performance indicators (market performance and profitability) with the moderating effect of external environment on the relationship between EO and firm performance.

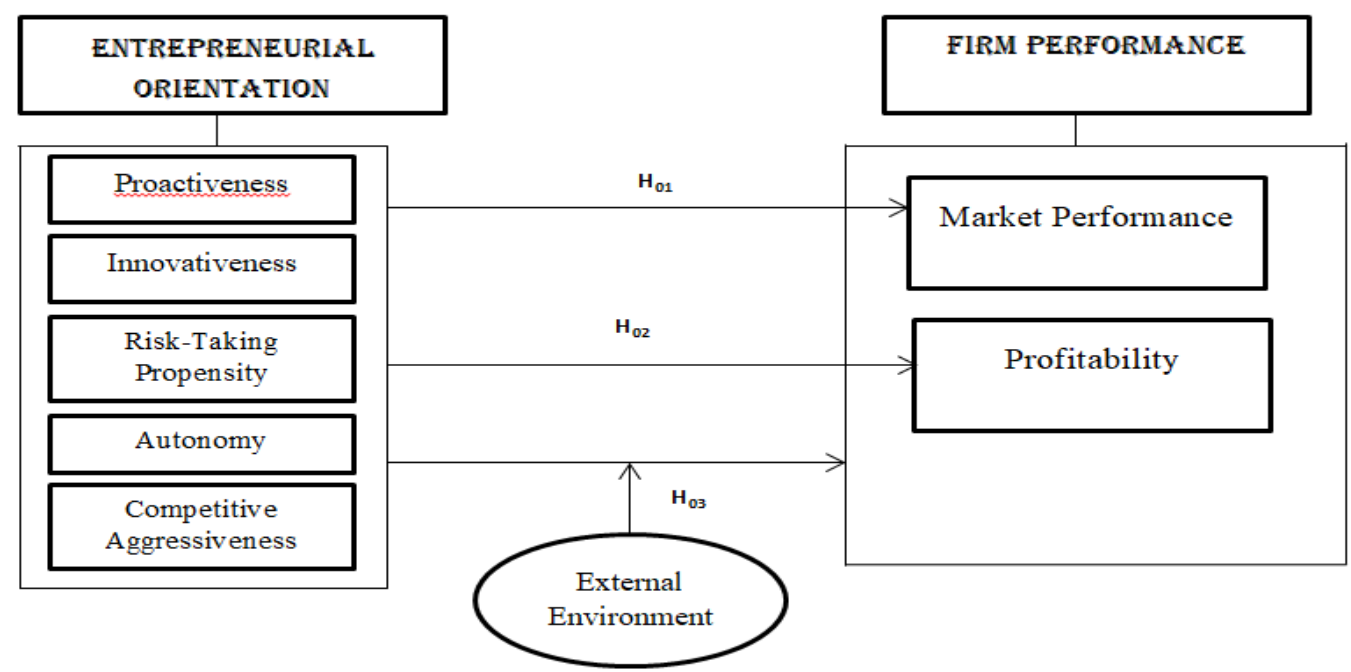

Figure 1. Conceptual model

Source: Researcher's Conceptual Model (2020)

\section{Materials and Methods}

This study employed survey research design through administration of questionnaire in order to investigate the interaction effect between entrepreneurial orientation, external environment and firm performance (market performance and profitability) of oil and gas service firms in Nigeria.

\subsection{Population}

The primary population of oil and gas service firms in Nigeria was 14,038 and the sample frame used in this study was the list of owner-managers and top managers like the heads of finance and planning functions of oil and gas service firms in Nigeria. Hence, a mixed sampling method was adopted in selecting the sample from the working population of this study.

\subsection{Sample Size}

The sample size for this study was determined by applying the Cochran (1997) formula. This is the standard method of randomization and it identifies the limits of errors considered as the most essential items in the survey. This helped the researcher to obtain the sample and use the results to make sampling decisions based on the data.

The formula is:

$$
\mathrm{n}=\frac{N Z^{2} p q}{\mathrm{~d}^{2}(\mathrm{~N}-1)+\mathrm{Z}^{2} \mathrm{pq}}
$$

Where:

$\mathrm{n}=$ sample size

$\mathrm{N}=$ Total number of oil and gas service firms $(\mathrm{N}=14,038)$ 
$Z=95 \%$ Confidence Interval $(Z=1.96)$,

$\mathrm{p}=0.5$

$\mathrm{q}=1-\mathrm{p}$

$\mathrm{d}=$ degree of accuracy or estimation $(\mathrm{d}=0.04)$

Therefore:

$$
\mathrm{n}=\frac{14,038(1.96)^{2}(0.5)(0.5)}{(0.04)^{2}(14,038-1)+(1.96)^{2}(0.5)(0.5)} \quad=576
$$

\subsection{Research Instrument}

The questionnaire used was validated and the reliability of the study variables were established. Construct and content validity were ascertained through checks and corrections from senior academics in the field of entrepreneurship and strategic management. The reliability of the research instrument was ascertained based on the Cronbach Alpha measure of reliability which is greater than 0.7. In this study EO served as the independent variable; firm performance measured by market performance and profitability were the dependent variables while external environment served as the moderating variable. For dependent and independent variables, a six points modified Likert scale type was used to elicit responses from every question in the questionnaire and this covered; Very High (VH) - 6; High (H) - 5; Moderately High (MH) - 4; Moderately Low (ML) - 3; Low (L) - 2; Very Low (VL) - 1. For the dependent variable: Decrease Greatly (DG) -6; Little Decrease (LD) -5; Almost the Same (AS) -4; The Same (TS) -3; Little Increase (LI) -2; and Increase Greatly (IG) -1.

\section{The Validity and Reliability Result}

Table 1. KMO, Bartlett's Test of Sphericity and Reliability Result

\begin{tabular}{lllllll}
\hline Variables & $\begin{array}{l}\text { Number } \\
\text { of } \\
\text { Questions }\end{array}$ & KMO & $\begin{array}{l}\text { Bartlett test } \\
\text { Sphericity }\end{array}$ & $\begin{array}{l}\text { Cronbach's } \\
\text { Alpha }\end{array}$ & Average Variance Explained \\
\hline Firm Profitability & 5 & 0.832 & 0.001 & 0.872 & 0.721 \\
\hline $\begin{array}{l}\text { Market } \\
\text { Performance }\end{array}$ & 5 & 0.731 & 0.000 & 0.830 & 0.801 \\
\hline Proactiveness & 5 & 0.782 & 0.000 & 0.782 & 0.762 \\
\hline Innovativeness & 5 & 0.619 & & 0.742 & 0.720 \\
\hline $\begin{array}{l}\text { Risk-Taking } \\
\text { Propensity }\end{array}$ & 5 & 0.701 & 0.001 & 0.832 & 0.643 \\
\hline Autonomy & 5 & 0.792 & 0.000 & 0.755 & 0.692 \\
\hline $\begin{array}{l}\text { Competitive } \\
\text { Aggressiveness }\end{array}$ & 5 & 0.721 & 0.000 & 0.820 & 0.729 \\
\hline $\begin{array}{l}\text { External } \\
\text { Environment }\end{array}$ & 12 & 0.891 & 0.000 & 0.872 & 0.793 \\
\hline Source: Fil & & & & & \\
\hline
\end{tabular}

Source: Field Survey (2020)

The result in Table 1 shown that the KMO is greater than 0.5 , it means that the questions actually measure the variables in the study. The result of the Bartlett test of Sphericity at 0.000 which is less than 5\%, indicate that there is highly significant relationship among variables in measuring the variables under study. In this study, the KMO test is greater than 5\% and Bartlett test of Sphericity result is less than 5\% indicating that statements that comprised the research instruments of each variable actually measured what were intended. The result of the KMO and Bartlett test of Sphericity are shown in Table 1 . The construct validity of the research instrument was further established through confirmatory factor analysis. Average Variance Extracted (AVE) greater than 0.5 was used as an additional evidence of construct validity of all variables in the research instrument. The results of the Cronbach Alpha were greater than 0.70 for each of the variable which indicated that the items used to measure study variables were reliable. 


\subsection{Model Specification}

The empirical model for the study was denoted as;

$\mathrm{Y}=$ Dependent Variable

$\mathrm{X}=$ Independent Variable

$\mathrm{Z}=$ External Environment $(\mathrm{EE})=$ Moderating Variable

$\mathrm{Y}=$ Firm Performance (FP)

Where:

$\mathrm{Y}=$ Firm Performance $(\mathrm{FP})=\mathrm{y}_{1}$, and $\mathrm{y}_{2}$

Where:

$\mathrm{y}_{1}=$ Market Performance (MP)

$\mathrm{y}_{2}=$ Profitability $(\mathrm{PR})$

$\mathrm{X}=$ Entrepreneurial Orientation (EO)

$\mathrm{x}_{1}=$ Proactiveness (PA)

$\mathrm{x}_{2}=$ Innovativeness (INO)

$\mathrm{x}_{3}=$ Risk-Taking Propensity (RTP)

$\mathrm{x}_{4}=$ Autonomy (AT)

$\mathrm{x}_{5}=$ Competitive Aggresiveness (CA)

$\beta_{0=}$ the constant term

$\beta_{1}-\beta_{5}=$ the regression coefficients

The model formulated for each of the hypotheses were written as:

\section{Hypothesis One}

$$
\begin{aligned}
& y_{1}=\beta_{0}+\beta_{1} x_{1}+\beta_{2} x_{2}+\beta_{3} x_{3}+\beta_{4} x_{4}+\beta_{5} x_{5}++\varepsilon_{i} \\
& M P=\beta_{0}+\beta_{1} P A+\beta_{2} I N N O+\beta_{3} R T P+\beta_{4} A T+\beta_{1} C A+\varepsilon_{i}
\end{aligned}
$$

Hypothesis Two

$$
\begin{aligned}
& y_{2}=\beta_{0}+\beta_{1} x_{1}+\beta_{2} x_{2}+\beta_{3} x_{3}+\beta_{4} x_{4}+\beta_{5} x_{5}++\varepsilon_{i} \\
& P R=\beta_{0}+\beta_{1} P A+\beta_{2} I N N O+\beta_{3} \mathrm{RTP}+\beta_{4} \mathrm{AT}+\beta_{1} \mathrm{CA}+\varepsilon_{\mathrm{i}}
\end{aligned}
$$

\section{Hypothesis Three}

$$
\begin{aligned}
& \mathrm{Y}=\beta_{0}+\beta_{\mathrm{i}} \mathrm{X}_{\mathrm{i}}+\beta_{\mathrm{z}} \mathrm{Z}+\beta_{\mathrm{iz}} \mathrm{X}_{\mathrm{i}} \mathrm{Z}+\varepsilon_{\mathrm{i}} \\
& \mathrm{FP}=\beta_{0}+\beta_{\mathrm{i}} \mathrm{EO}_{\mathrm{i}}+\beta_{\mathrm{z}} \mathrm{EE}_{\mathrm{i}}+\beta_{\mathrm{iz}} \mathrm{EO} * \mathrm{EE}_{\mathrm{i}}+\varepsilon_{\mathrm{i}}
\end{aligned}
$$

\section{Results and Discussions}

This sub-section shows the response rate and analysis of the source data.

In this study, 576 questionnaire was administered and 552 of the administered questionnaire was retrieved and analysed representing a response rate of $95.83 \%$. 


\subsection{Correlation Matrix}

Table 2. Correlation coefficients for Multicollinearity Test

\begin{tabular}{|c|c|c|c|c|c|c|c|c|}
\hline Variables & MP & PR & PA & INNO & RTP & AT & $\mathrm{CA}$ & Variance Inflation Factor (VIF) \\
\hline MP & 1 & & & & & & & 3.73 \\
\hline PR & 0.511 & 1 & & & & & & 2.86 \\
\hline $\mathrm{PA}$ & 0.321 & 0.173 & 1 & & & & & 3.83 \\
\hline INNO & 0.343 & 0.335 & 0.421 & 1 & & & & 2.47 \\
\hline RTP & 0.198 & 0.423 & 0.120 & 0.076 & 1 & & & 3.99 \\
\hline AT & 0.598 & 0.512 & 0.067 & 0.421 & 0.701 & 1 & & 3.81 \\
\hline $\mathrm{CA}$ & 0.410 & 0.698 & 0.734 & 0.219 & 0.056 & & 1 & 2.06 \\
\hline
\end{tabular}

Source: Field Survey (2020)

The correlation matrix of variables is presented in Table 8 in order to show the relationship that exists among the variables and to also verify if none of the relationships among the explanatory variables of the models have correlation coefficient as high as 0.8 , which is a threshold above which inclusion of such variables in the same model would cause a problem of severe multicollinearity in the model. Since the correlation coefficient of the explanatory variables were less than 0.8 for all the variables measured, this shows that no existence of multicollinearity among the study explanatory variables. Furthermore, the result of the VIF shows that the value of the VIF; 3.73, 2.86, 3.83, 2.47, 3.99, 3.81 and 2.06 for MP, PR, PA, INNO, RTP, AT and CA respectively were less than 5. Therefore, there is no problem of multicollinearity in the model.

Table 3. Model One: Regression results on the effect of entrepreneurial orientation components on market performance of oil and gas service firms in Nigeria

\begin{tabular}{|c|c|c|c|c|c|c|c|c|c|c|}
\hline Model & B & $\begin{array}{l}\text { Std. } \\
\text { Error }\end{array}$ & Beta & $\mathbf{T}$ & Sig. & $\mathbf{R}$ & Adj. $R^{2}$ & F-Value & Sig. & $\begin{array}{l}\text { Durbin- } \\
\text { Watson }\end{array}$ \\
\hline (Constant) & .633 & .304 & & 2.081 & .038 & 0.621 & 0.538 & 92.142 & 0.000 & 1.725 \\
\hline Proactiveness & .105 & .047 & .107 & 2.208 & .028 & & & & & \\
\hline Innovativeness & .018 & .147 & .214 & 0.660 & .720 & & & & & \\
\hline $\begin{array}{l}\text { Risk-Taking } \\
\text { Propensity }\end{array}$ & -.030 & .152 & -.031 & -1.987 & .027 & & & & & \\
\hline Autonomy & .585 & .040 & .690 & 4.458 & .050 & & & & & \\
\hline $\begin{array}{l}\text { Competitive } \\
\text { Aggressiveness }\end{array}$ & 2.732 & .923 & 1.352 & 5.821 & .002 & & & & & \\
\hline
\end{tabular}

Dependent Variable: Market Performance (MP)

Source: Authors' Computation (2020)

Table 3 for model one, revealed that coefficient of relative effect $(\mathrm{R}=0.621)$ shows a strong positive correlation exists between EO components (proactiveness, innovation, risk-taking propensity, autonomy and competitive 
aggressiveness) and market performance. Also, the Durbin-Watson revealed that there is no problem of serial correlation in the aggregate regression model as the value of the Durbin-Watson is close to 2.00. The coefficient of determination (Adj. $\mathrm{R}^{2}$ ) of 0.538 shows that EO components explained $53.8 \%$ of variation in market performance. However, the model did not explain $46.2 \%$ of the variation in market performance, implying that there are other factors that determined market performance which was not captured in the model. Additionally, Table 3 also shows the ANOVA result. The result revealed that overall, the explanatory power of the model was considered statistically significant with the F-stat value output of the model reporting a p-value of $.000(\mathrm{~F}=92.142, \mathrm{p}<0.05)$. This indicated that EO components have significant effect on market performance of oil and gas service firms in Nigeria. Similarly, as depicted in Table 3, among the EO components, the best rank predictors of market performance were competitive aggressiveness, risk-taking propensity, proactiveness, autonomy and lastly innovativeness since the F-value for the aggregate model was less than 5\% level of significance. The results reveal that Competitive Aggressiveness $(\beta=$ 2.732, $p=.002)$, Risk-Taking Propensity ( $\beta=-.030, p=.027)$, Proactiveness $(\beta=.105, p=.028)$, and Autonomy $(\beta=.585$, $p=.050$ ) were statistically significant to market performance at $5 \%$ level of significance except for innovativeness ( $\beta=.018, p=.720)$. Therefore, this study rejected the null hypothesis one that:

$\mathbf{H}_{01}$ : Entrepreneurial orientation components (proactiveness, innovativeness, risk taking propensity, autonomy and competitive aggressiveness) do not significantly affect market performance of oil and gas service companies in Nigeria

Table 4. Model Two: Regression results on the effect of entrepreneurial orientation components on profitability of oil and gas service firms in Nigeria

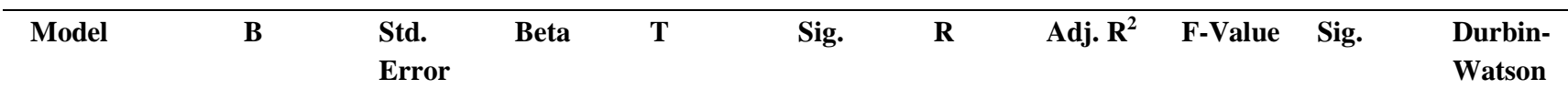

\begin{tabular}{|c|c|c|c|c|c|c|c|c|c|c|}
\hline (Constant) & .212 & .308 & & 1.690 & .040 & 0.73 & 0.626 & 76.584 & 0.000 & 1.913 \\
\hline Proactiveness & 2.303 & .048 & -.003 & -.071 & .033 & & & & & \\
\hline Innovativeness & .158 & .047 & .147 & 3.334 & .001 & & & & & \\
\hline $\begin{array}{l}\text { Risk-Taking } \\
\text { Propensity }\end{array}$ & -.179 & .052 & .176 & 3.437 & .001 & & & & & \\
\hline Autonomy & 1.589 & .041 & .662 & 14.319 & .000 & & & & & \\
\hline $\begin{array}{l}\text { Competitive } \\
\text { Aggressiveness }\end{array}$ & 3.054 & 1.422 & .832 & 5.094 & .000 & & & & & \\
\hline
\end{tabular}

Dependent Variable: Profitability (PR)

Source: Authors' Computation (2020)

Table 4 for model two, revealed that coefficient of relative effect $(R=0.73)$ shows a strong positive correlation exists between EO components (proactiveness, innovation, risk-taking propensity, autonomy and competitive aggressiveness) and profitability of oil and gas service firms in Nigeria. Also, the Durbin-Watson revealed that there is no problem of serial correlation in the aggregate regression model as the value of the Durbin-Watson is close to 2.00. The coefficient of determination (Adj. $\mathrm{R}^{2}$ ) of 0.626 shows that $\mathrm{EO}$ components explained $62.6 \%$ of variation in profitability. However, the model did not explain $37.4 \%$ of the variation in profitability, implying that there are other factors that determined profitability which were not captured in the model. Additionally, Table 4 also shows the ANOVA result. The result revealed that overall, the explanatory power of the model was considered statistically significant with the F-stat value output of the model reporting a p-value of $.000(\mathrm{~F}=76.584, \mathrm{p}<0.05)$. This indicated that EO components have significant effect on profitability of oil and gas service firms in Nigeria. Similarly, as depicted in the Table 4 above, among the EO components, the best rank predictors of profitability were autonomy, competitive aggressiveness, innovativeness, risk-taking propensity and proactiveness since the F-value for the 
aggregate model was less than $5 \%$ level of significance. The results reveal that Autonomy $(\beta=1.589, p=.000)$, Competitive Aggressiveness $(\beta=3.054, p=.000)$, Risk-Taking Propensity $(\beta=-.179, p=.001)$, Innovativeness $(\beta=.158, p=.001)$, and Proactiveness $(\beta=2.303, p=.033)$ were all statistically significant to profitability at $5 \%$ level of significance. Therefore, this study rejected the null hypothesis two that:

$\mathbf{H}_{02}$ : Entrepreneurial orientation components (proactiveness, innovativeness, risk taking propensity, autonomy and competitive aggressiveness) do not significantly affect profitability of oil and gas service companies in Nigeria

Table 5a. Model summary for moderating effect of external environment on the relationship between entrepreneurial orientation and firm performance of oil and gas service companies in Nigeria

\begin{tabular}{|c|c|c|c|c|c|c|c|c|c|c|}
\hline \multicolumn{11}{|c|}{ (a)Model Summary } \\
\hline \multirow[t]{3}{*}{ Model } & \multirow[t]{3}{*}{$\mathrm{R}$} & \multirow[t]{3}{*}{ R Square } & \multirow{3}{*}{$\begin{array}{l}\text { Adjusted } \\
\text { Square }\end{array}$} & \multirow[t]{3}{*}{$\mathrm{R}$} & \multirow{3}{*}{$\begin{array}{l}\text { Std. Error of } \\
\text { the Estimate }\end{array}$} & \multicolumn{5}{|c|}{ Change Statistics } \\
\hline & & & & & & $\begin{array}{ll}\mathrm{R} & \text { Square }\end{array}$ & F Change & $\mathrm{df} 1$ & df2 & Sig. F Change \\
\hline & & & & & & \multicolumn{5}{|l|}{ Change } \\
\hline 1 & $0.231^{\mathrm{a}}$ & 0.390 & 0.412 & & 1.5691091 & 0.330 & 98.233 & 1 & 576 & 0.001 \\
\hline 2 & $0.304^{\mathrm{b}}$ & 0.481 & 0.487 & & 1.6758056 & 0.437 & 57.784 & 1 & 575 & 0.020 \\
\hline 3 & $0.453^{\mathrm{c}}$ & 0.520 & 0.593 & & .87343611 & 0.541 & 25.451 & 1 & 574 & 0.001 \\
\hline
\end{tabular}

a. Predictors: (Constant), Entrepreneurial Orientation

b. Predictors: (Constant), Entrepreneurial Orientation, External Environment

c. Predictors: (Constant), Entrepreneurial Orientation, External Environment, Entrepreneurial Orientation x External Environment

d. Dependent Variable: Firm Performance

Source: Field Survey Result (2020).

Table 5b. ANOVA result

\begin{tabular}{lllllll}
\hline ANOVA & & & & \\
\hline \multicolumn{2}{l}{ Model } & Sum of Squares & Df & Mean Square & F & Sig. \\
\hline \multirow{2}{*}{1} & Regression & 409.605 & 1 & 232.315 & 92.415 & $.000^{\mathrm{b}}$ \\
\cline { 2 - 7 } & Residual & 166.395 & 575 & .581 & & \\
\cline { 2 - 7 } & Total & 576.000 & 576 & & & \\
\hline 2 & Regression & 452.876 & 2 & 101.318 & 69.510 & $.000^{\mathrm{c}}$ \\
\cline { 2 - 7 } & Residual & 123.124 & 574 & .390 & & \\
\cline { 2 - 7 } & Total & 576.000 & 576 & & & \\
\hline 3 & Regression & 498.692 & 3 & 86.421 & & \\
\cline { 2 - 6 } & Residual & 77.308 & 573 & .398 & & \\
\cline { 2 - 6 } & Total & 576.000 & 576 & & & \\
\hline
\end{tabular}


Table 5c. Coefficients

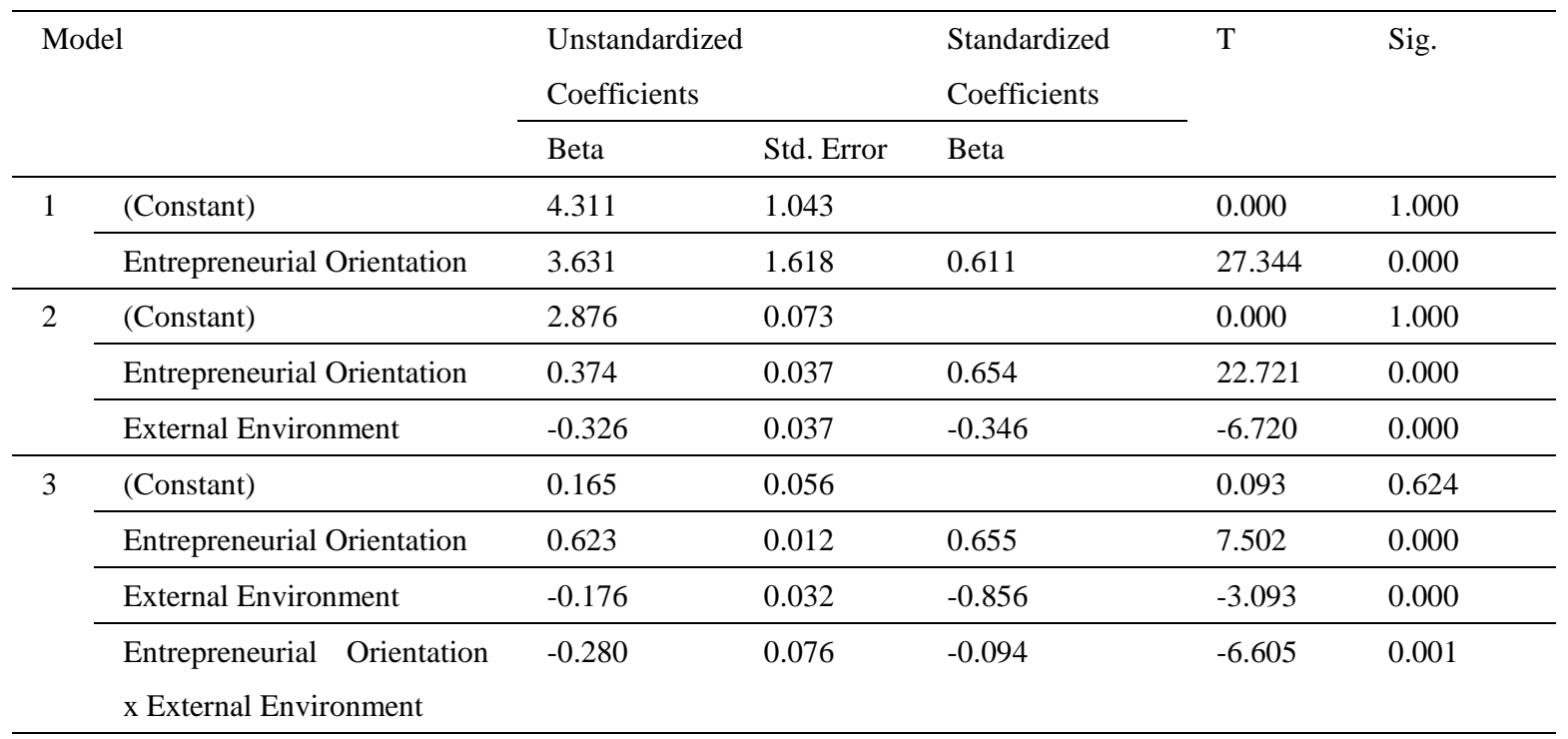

a. Dependent Variable: Firm Performance

b. Predictors: (Constant), Entrepreneurial Orientation

c. Predictors: (Constant), Entrepreneurial Orientation, External Environment

d. Predictors: (Constant), Entrepreneurial Orientation, External Environment, Entrepreneurial Orientation x External Environment

Source: Field Survey Result (2020).

Tables 5a depicted hierarchical multiple regression results for the moderating effect of external environment on the relationship between EO and firm performance. Results in Table 5a summarise the output for the analysis if moderation effect is not considered. From Table 5a, Model 1 revealed that $\mathrm{R}=0.231, \mathrm{R}^{2}=0.320$ and $[\mathrm{F}(1,576)=$ 98.233, $\mathrm{p}=.0000]$. The value of coefficient of determination, $\mathrm{R}^{2}$ indicates that $32 \%$ of the variance in the performance of oil and gas service firms in Nigeria was accounted for by EO. The remaining $68 \%$ of the total variation in firm performance was explained by factors not included in the model. After considering the moderator (external environment) in the model 3, the adjusted R-square value was $0.523(52.3 \%)$ and the explained variation in the relationship of study variables was found to be significant $(\mathrm{p}=0.001<0.05)$. This indicated that external environment as moderator with EO significantly determines performance of oil and gas service firms in Nigeria. Furthermore, in Table 5b, after considering the moderating variable (external environment) with independent variable (entrepreneurial orientation); the F-statistics is 47.215 with a corresponding p-value of 0.000 (p-value < 0.05). Result in Table 5c indicates that the interaction term of EO and external environment has a beta coefficient of -.280 and a corresponding $p$-value of 0.001 which implies that the relationship is negative and statistically significant $(\mathrm{p}<0.05)$. This indicates that external environment significantly moderates the relationship between EO and performance of oil and gas service firms in Nigeria. Based on these results in Table 5a, 5b and 5c, this study therefore rejected null hypothesis three $\left(\mathrm{H}_{03}\right)$ that:

$\mathbf{H}_{\mathbf{0 3}}$ : There is no significant moderating effect of external environment on the relationship between entrepreneurial orientation and firm performance of oil and gas service companies in Nigeria

The findings of this study were consistent with the empirical findings of many past studies (Chow, 2006; Couto-Soares \& Perin, 2019; Garba et al., 2019; Irungu \& Moronge, 2018; Kimutai-Arap-Bor, 2018; Kosa et al., 2018; Mahmood \& Hanafi, 2013; Peng, 2015; Syrja et al., 2019; Tang et al., 2007; Uchenna et al., 2019; Wambugu et al., 2016; Wiklund \& Sheperd, 2003 among others) to the effect that EO measures have positive and significant effect on firm overall performance outcomes. Therefore, this study rejected the null hypotheses one and two that EO components (proactiveness, innovativeness, risk taking propensity, autonomy and competitive aggressiveness) do not significantly affect firm overall performance.

The finding with respect to hypotheses three is congruent with empirical findings in such past studies as Lee and Chu (2013) which found that environmental dynamism moderates EO-performance relationship; Milovanovic and Wittine 
(2014) which indicated that external environment has a positive influence on the relationship between EO and small business performance; Omisakin et al. (2016) which confirmed that environmental variables influence and moderate the relationship between EO and firm performance; Shirokova et al. (2016) which confirmed that firms achieve superior performance when adopting EO in environments with high levels of both hostility and market growth while lower firm performance is achieved in favourable environments with low hostility and high market growth; and Wiklund and Shepherd (2003) which reported that environmental munificence moderates the EO-firm performance relationship. Therefore, this study rejected the null hypotheses three that there is no significant moderating effect of external environment on the relationship between EO and firm performance of oil and gas service companies in Nigeria.

\section{Conclusion and Recommendations}

This study concluded that EO components ((proactiveness, innovativeness, risk taking propensity, autonomy and competitive aggressiveness) determine firm performance oil and service firms in Nigeria. Also, external environment moderate, determine and affect the relationship between EO and overall performance of oil and gas service firms in Nigeria. Based on the findings, the study recommends that:

(i) Executives of oil and gas service firms to encourage and stimulate their employees to participate in activities that involve creativity, proactivity, experimentation and propensity to assume risks so as increase market performance.

(ii) Managers should encourage the development of a culture that fosters sound entrepreneurship ideas, openness to innovation, new process, product, or new ideas within the organization in order to enhance profitability of oil and gas service firms in Nigeria.

(iii) Owner/managers of these oil and gas service firms in Nigeria should critically consider external environmental factors in designing their business strategies towards superior overall firm performance.

(iv) Policy makers and industry regulators should pay adequate attention to improvements in the business environment which is found to be critical to the development policy formulation of these oil service firms most of which are small and medium enterprises. This is as a result of EO being found to be increasingly shaped by business environmental factors.

\section{Limitations and Suggestions for Further Studies}

Like other studies, this study has some limitations which must be considered in determining areas for further research. First, the study was limited to the oil and gas service sector of the industry. For a more holistic picture of entrepreneurial mindset and practices in the entire industry, the variables could also be investigated in both the other sectors of the oil and gas industry. Second, the institutional and regulatory weaknesses of Nigeria as a developing economy commends the replication of the study of these variables in both the developed and other emerging oil producing countries for comparison of results. Third, the study used a cross sectional survey design and such studies cannot be used to analyse the behaviour of a variable (EO-firm performance relationship) over a period of time and do not detect causal effects of variables as a longitudinal survey would do. Fourth, EO was treated as a multidimensional construct in this study though there are studies that took EO as a unidimensional construct and this could affect the results of the tests. Fifth, literature has also confirmed that the different dimensions of EO do relate differentially to performance under different circumstances including under different national and organizational culture conditions. Therefore, further studies should investigate the effect of EO on performance of oil and gas upstream and downstream industries with national and/or organizational culture as moderating variable.

\section{References}

Achrol, R. S. (1991). Evolution of the marketing organization: new forms for turbulent environments. Journal of Marketing, 55, 77-93.

Adesanya, O. D., Iyiola, O. O., Borishade, T. T., Dirisu, J. I., Olokundun, M. A., Ibidunni, A. S., \& Omotoyinbo, C. A. (2018). Entrepreneurial orientation and business performance of non-oil exporting SMEs in Lagos State, Nigeria. International Journal of Entrepreneurship, 22(3), 1-7.

Adi, Z. A. (2015). Strategic human resource management, innovation capability and performance: An empirical study in Indonesia software industry. Procedia-Social and Behavioral Sciences, 211, 874-879.

Agbaeze, E. K., \& Ukoha, K. (2018). Oil a blessing or a curse: The Nigerian experience. European Journal of Social Sciences, 56(3), 262-270.

Ariguzo, A. A., Abimbola, M. M., \& Egwakhe, J. A. (2018). Strategies and Entrepreneurial Success: An assessment of selected female owned micro \& small businesses in Ikenne LGA, Ogun State, Nigeria. European Journal of 
Business and Management, 10(5), 74-83.

Arokodare, M. A. (2018). Strategic entrepreneurship and performance of selected oil and gas service firms in Lagos and Rivers States, Nigeria. Unpublished MPhil Dissertation, Babcock University, Ilishan-Remo, Nigeria.

Asagunla, T. M., \& Agbede, M. O. (2018). Oil revenue and output growth in Nigeria. International Journal of Economics and Business Management, 4(6), 65-74.

Asikhia, O. U., \& Arokodare, M. A. (2019). Planning flexibility, environmental uncertainty and organizational performance of selected oil and gas service firms in Lagos and Rivers States, Nigeria. IOSR Journal of Business and Management (IOSR-JBM), 21(6), 25-32.

Barreto, I. (2010). Dynamic capabilities: A review of past research and an agenda for the future. Journal of Management, 36(1), 256-280.

Bloch, H., \& Bhattacharya, M. (2016). Promotion of innovation and job growth in small and medium, sized enterprises in Australia: Evidence and policy issues. Australian Economic Review, 49(2), 192-199.

Boohene, R. (2018). Entrepreneurial orientation, strategic orientation and performance of small family firms in the Kumasi Metropolis. Academy of Entrepreneurship Journal, 24(2), 1-23.

Chow, I. H. S. (2006). The relationship between entrepreneurial orientation and firm performance in China. SAM Advanced Management Journal, 71(3), 11-21.

Cochran, W. G. (1977). Sampling techniques (3rd ed.). New York: John Wiley \& Sons.

Couto-Soares, M., \& Perin, M. G. (2019). Entrepreneurial orientation and firm performance: an updated meta-analysis. RAUSP Management Journal, 1-15.

Covin, J. G., \& Slevin, D. P. (1991). A conceptual model of entrepreneurship as firm behaviour. Entrepreneurship Theory and Practice, 16(1), 7-25.

Dai, L., Maksimov, V., Gilbert, B. A., \& Fernhaber, S. A. (2014). Entrepreneurial orientation and international scope: The differential roles of innovativeness, proactiveness, and risk-taking. Journal of Business Venturing, 29(4), 511-524.

Deakins, D., \& Freel, M. (2012). Entrepreneurship and small firms (6th ed.). McGraw Hills Higher Education.

Deepa-Babu, K. G., \& Manalel, J. (2016). Entrepreneurial orientation and firm performance: a critical examination. Journal of Business and Management, 18(4), 211-228.

Di Stefano, G., Peteraf, M., \& Verona, G. (2010). Dynamic capabilities deconstructed: A bibliographic investigation into the origins, development, and future directions of the research domain. Industrial and Corporate Change, 19(4), 1187-1204.

Eisenhardt, K. M. (2013). Top management teams and the performance of entrepreneurial firms. Small Business Economics, 40(4), 805-816.

Fadda, N. (2018). The effects of entrepreneurial orientation dimensions on performance in the tourism sector. New England Journal of Entrepreneurship, 21(1), 22-44.

Freiling, J., \& Lütke Schelhowe, C. (2014). The impact of entrepreneurial orientation on the performance and speed of internationalization. Journal of Entrepreneurship, Management and Innovation, 10(4), 169.

Garba, A. S., Kabir, I., \& Mahmoud, M. A. (2019). Entrepreneurial orientation and growth potential of microenterprises in Northwest, Nigeria. Journal of Developmental Entrepreneurship, 24(02), 1-20.

George, B. A., \& Marino, L. (2011). The epistemology of entrepreneurial orientation: Conceptual formation, modeling, and operationalization. Entrepreneurship Theory and Practice, 35(5), 989-1024.

Gudda, O. F. (2018). Effect of entrepreneurial orientation on SMEs product innovativeness. International Journal of Management and Commerce Innovations, 5(2), 829-833.

Gupta, V. K., Niranjan, S., Goktan, B. A., \& Erikson, J. (2015). Individual entrepreneurial orientation role in shaping reactions to new technologies. International Entrepreneurship and Management Journal, 12(4), 935-961.

Hakala, H. (2011). Strategic orientation management in literature: Three approaches to understanding the interraction between market, technology, and entrepreneurial orientation. International Journal of Management Review, 13(2), 198-205.

Hughes, M., \& Morgan, R. E. (2007). Deconstructing the relationship between entrepreneurial orientation and 
business performance at the embryonic stage of firm growth. Industrial Marketing Management, 36(5), 651-661.

Hult, G. T. M., Hurley, R. F., \& Knight, G. A. (2004). Innovativeness: Its antecedents and impact on business performance. Industrial Marketing Management, 33, 429-438.

Ihua, U. B., Olabowale, O. A., Eloji, K. N., \& Ajayi, C. (2011). Entrepreneurial implications of Nigeria's oil industry local content policy. Journal of Enterprising Communities: People and Places in the Global Economy, 5(3), 223-241.

Irungu, J. N., \& Moronge, M. (2018). Influence of entrepreneurial orientation on growth of dairy agribusinesses in small and medium enterprises in Naivasha sub-county, Kenya. The Strategic Journal of Business and Change Management, 5(4), 1411-1424.

Ketchen, D., \& Short, J. (2012). Strategic management: Evaluation and execution. Retrieved from http://2012books.lardbucket.org/books/strategic-management-evaluation-andexecution/index.html

Kimutai-Arap-Bor, G. (2018). A descriptive analysis of the influence of entrepreneurial orientation dimensions on the performance of SMEs in Kenya. International Journal of Small Business and Entrepreneurship Research, $6(1), 31-45$.

Kosa, A., \& Mohammad, I., \& Ajibie, D. (2018). Entrepreneurial orientation and venture performance in Ethiopia. The moderating role of business sector and enterprise location. Journal of Global Entrepreneurship Research, $8(1), 1-17$.

Kosgei, C. N., \& Loice, M. C. (2015). Entrepreneurial orientation and firm performance: Evidence from small and micro-enterprises in Kenya. European Journal of Business and Management, 7(27), 187-196.

Kotter, J. P. (1996). Kill complacency. Fortune, 5, 122-4.

Kreiser, P. M., Marino, L. D., \& Weaver, K. M. (2002). Reassessing the environment-EO link: The impact of environmental hostility on the dimensions of entrepreneurial orientation. In Academy of Management Proceedings, 2002(1), G1-G6.

Kreiser, P. M., Marino, L. D., Kuratko, D. F., \& Weaver, K. M. (2013). Disaggregating entrepreneurial orientation: the non-linear impact of innovativeness, proactiveness and risk-taking on SME performance. Small Business Economics, 40(2), 273-291.

Lebans, M., \& Euske, K. (2006). A conceptual and operational delineation of performance. Business performance measurement. Cambridge University Press.

Lee, T., \& Chu, W. (2013). How entrepreneurial orientation, environmental dynamism, and resource rareness influence firm performance. Journal of Management \& Organization, 19(2), 167-187.

Li, Y. H., Huang, J. W., \& Tsai, M. T. (2009). Entrepreneurial orientation and firm performance: The role of knowledge creation process. Industrial Marketing Management, 38(4), 440-449.

Lisboa, A., Skarmeas, D., \& Lages, C. (2011). Entrepreneurial orientation, exploitative and explorative capabilities, and performance outcomes in export markets: A resource-based approach. Industrial Marketing Management, 40 (8), 1274-1284.

Lumpkin, G. T., \& Dess, G. G. (1996). Clarifying the entrepreneurial orientation construct and linking it to performance. The Academy of Management Review, 21(1), 135-172.

Lumpkin, G., \& Dess, G. G. (2001). Linking two dimensions of entrepreneurial orientation to firm performance: The moderating role of environment and industry life cycle. Journal of Business Venturing, 429-451.

Mahmood, R., \& Hanafi, N. (2013). Entrepreneurial orientation and business performance of women-owned small and medium enterprises in Malaysia: Competitive advantage as a mediator. International Journal of Business and Social Science, 4(1), 82-90.

Maragia, I. (2008) Factors that determine entrepreneurial behaviour in micro and small enterprises (MSEs) in Kenya. Scan Graphics Kenya Ltd.

Mason, R. B., \& Dobbelstein, T. (2016). The influence of the level of environmental complexity and turbulence on the choice of marketing tactics. Journal of Economics and Behavioral Studies, 8(2), 40-55.

Masona, C. M., Floreania, J., Miania, S., Beltramea, F., \& Cappelletto, R. (2015). Understanding the Impact of entrepreneurial orientation on SMEs' performance. The role of the financing structure. Procedia Economics and 
Finance, 23, 1649-1661.

Milovanovic, B. M., \& Wittine, Z. (2014). Analysis of external environment's moderating role on the entrepreneurial orientation and business performance relationship among Italian small enterprises. International Journal of Trade, Economics and Finance, 5(3), 224-229.

Montoya, R. A. C., Martins, I., \& Ceballos, H. Z. (2017). Entrepreneurial orientation, assessment and management of projects and impact in corporate entrepreneurship: Intention to action. Cuadernos de Gestión, 17(2), 37-62.

Naldi, L., Nordqvist, M., Sjöberg, K., \& Wiklund, J. (2007). Entrepreneurial orientation, risk taking, and performance in family firms. Family Business Review, 20(1), 33-47.

National Bureau of Statistics. (2018). First Quarter Report on Gross Domestic Product. Retrieved from https://africacheck.org/reports/nigerias-economy-services-drive-gdp-but-oil-still-dominates-exports/

Nikolov, K., \& Urban, B. (2013). Sustainable corporate entrepreneurship initiatives: A risk and reward analysis. Technological and Economic Development of Economy, 19, 383-408.

Njoroge, J. K., Ongeti, W. J., Kinuu, D., \& Kasomi, F. M. (2016). Does external environment influence organizational performance? The case of Kenyan State Corporations. Management and Organizational Studies, $3(3), 41-51$.

Njuguna-Kinyua, J., Munyoki, J., \& Kibera, F. (2014). Influence of external organizational environment on performance of community-based HIV and AIDS organizations in Nairobi County, Kenya. European Scientific Journal, 10(28), 405-426.

Olawoye, O. (2016). Role of entrepreneurial orientation on performance of firms in the Nigerian Stock Exchange. (Doctoral Thesis). Jomo Kenyatta University of Agriculture and Technology, Kenya.

Omisakin, O., Nakhid, C., Littrell, R., \& Verbitsky, J. (2016). Entrepreneurial orientation among migrants and small and medium enterprises. Journal of Business Administration Research, 5(1), 7-22.

Patzelt, H., \& Shepherd, D. A. (2009). Strategic entrepreneurship at universities: Academic entrepreneurs' assessment of policy programs. Entrepreneurship Theory and Practice, 33(1), 319-340.

Peng, X. (2015). Risk taking and firm growth. RIETI Discussion Paper Series 15-E-061.

Rauch, A., Wiklund, J., Lumpkin, G. T., \& Frese, M. (2009). Entrepreneurial orientation and business performance: An assessment of past research and suggestions for the future. Entrepreneurship Theory and Practice, 33(3), 761-787.

Renko, M., Carsrud, A., \& Brännback, M. (2009). The effect of a market orientation, entrepreneurial orientation, and technological capability on innovativeness: a study of young biotechnology ventures in the United States and in Scandinavia. Journal of Small Business Management, 47, 331-369.

Rezaei, J., \& Ortt, R. (2018). Entrepreneurial orientation and firm performance: the mediating role of functional performances. Management Research Review, 878-900.

Ribeiro-Soriano, D., \& Urbano, D. (2010). Employee- organization relationship in collective entrepreneurship: An overview. Journal of Organizational Change Management, 23(4), 349-359.

Rigtering, J. C., Eggers, F., Kraus, S., \& Chang, M. L. (2017). Entrepreneurial orientation, strategic planning and firm performance: The impact of national cultures. European Journal of International Management, 11, 301-324.

Saeed, S., Yousafzai, S. Y., \& Engelen, A. (2014). On cultural and macroeconomic contingencies of the entrepreneurial orientation performance relationship. Entrepreneurship Theory \& Practice, 38(2), 255-290.

Santos, J. B., \& Brito, L. A. L. (2012). Toward a subjective measurement model for firm performance. Brazilian Administration Review, 9(6), 95-117.

Schepers, J., Voordeckers, W., Steijvers, T., \& Laveren, E. (2014). The entrepreneurial orientation-performance relationship in private family firms: The moderating role of socio-emotional wealth. Small Business Economics, 43(1), 39-55.

Schillo, S. (2011). Entrepreneurship orientation and company performance: Can the academic literatures guide managers? Technology Innovation Management Review, 1(2), 20-25.

Selvam, M., Gayathri, J., Vasanth, V., Lingaraja, K., \& Marxiaoli, S. (2016). Determinants of firm performance: A subjective model. International Journal of Social Science Studies, 4(7), 90-100. 
Shirokova, G., Bogatyreva, K., Beliaeva, T., \& Puffer, S. (2016). Entrepreneurial orientation and firm performance in different environmental settings. Journal of Small Business and Enterprise Development, 23(3), 703-727.

Slater, S. F., \& Narver, J. C. (2000). The positive effect of a market orientation on business profitability: A balanced replication. Journal of Business Research, 48, 69-73.

Song, W., Ma, X., \& Yu, H. (2019). Entrepreneurial orientation, interaction orientation, and innovation performance: A model of moderated mediation. Sage Open, 1-13.

$\mathrm{Su}, \mathrm{Z}$., Xie, E., \& Li, Y. (2011). Entrepreneurial orientation and firm performance in new ventures and established firms. Journal of Small Business Management, 49(4), 558-577.

Sumiati, F., Rofiq, A., \& Pramono, S. (2019). The role of strategic planning and flexibility in shaping SMEs market orientation in turbulence business environment. European Research Studies Journal, 10(1), 221-236.

Syrjä, P., Puumalainen, K., Sjögrén, H., Soininen, J., \& Durst, S. (2019). Entrepreneurial orientation in firms with a social mission: A mixed-methods approach. Cogent Business \& Management, 1-25.

Tang, J., Tang, Z., Zhang, Y., \& Li, Q. (2007). The impact of entrepreneurial orientation and ownership type on firm performance in the emerging region of China. Journal of developmental Entrepreneurship, 12(04), 383-397.

Teece, D. J. (2007). Explicating dynamic capabilities: The nature and micro foundations of (sustainable) enterprise performance. Strategic Management Journal, 28(13), 1319-1350.

Teece, D. J. (2018). Business models and dynamic capabilities. Long Range Planning, 51(1), 40-49.

Teece, D. J., Pisano, G., \& Shuen, A. (1997). Dynamic capabilities and strategic management. Strategic Management Journal, 18(7), 509-533.

Tolbert, P. S., \& Hall, R. (2009). Organizations: structure, processes and outcomes. UK: Pearson.

Uchenna, E. B., Sanjo, O. M., \& Joseph, F. (2019). Entrepreneurial orientation and micro, small and medium enterprises (MSMES) Performance in Abia State, Nigeria. Covenant Journal of Entrepreneurship, (Special Edition), 3(1).

Van Doorn, S., Heyden, M. L., \& Volberda, H. W. (2017). Enhancing entrepreneurial orientation in dynamic environments: The interplay between top management team advice-seeking and absorptive capacity. Long Range Planning, 50, 134-144.

Wales, W. J., Gupta, V. K., \& Mousa, F. (2013). Empirical research on entrepreneurial orientation: An assessment and suggestions for future research. International Small Business Journal and Researching Entrepreneurship, 31, $357-383$.

Wales, W., Gupta, V. K., Marino, L., \& Shirokova, G. (2019). Entrepreneurial orientation: International, global and cross-cultural research. International Small Business Journal, 37, 95-104.

Wambugu, A. W., Gichira, R., \& Wanjau, K. (2016). Influence of entrepreneurial orientation on firm performance of Kenya's agro processing small and medium enterprises. Journal of Business and Management, 18(9), 89-96.

Wang, C. L. (2008). Entrepreneurial orientation, learning orientation, and firm performance. Entrepreneurship Theory and Practice, 32, 635-657.

Wiklund, J., \& Sheperd, D. A. (2003). Knowledge-based resources, entrepreneurial orientation, and the performance of small and medium-sized business. Strategic Management Journal, 24(13), 1307-1314.

Wiklund, J., \& Shepherd, D. (2005). Entrepreneurial orientation and small business performance: A configurational approach. Journal of Business Venturing, 20(1), 71-91.

World Bank. (2019). World Bank Nigeria economic update on Nigerian oil and gas economic report. World Bank Group.

Zafari, H. (2017). Marketing strategies to enhance profitability among international oil and gas service companies. Walden Dissertations and Doctoral Studies.

Zahra, S. A., \& Garvis, D. M. (2000). International corporate entrepreneurship and firm performance: the moderating effect of international environmental hostility. Journal of Business Venturing, 15, 469-492.

Zhao, Y. L., Song, M., \& Storm, G. L. (2013). Founding team capabilities and new venture performance: The mediating role of strategic positional advantages. Entrepreneurship Theory and Practice, 37(4), 789-814. 